\title{
6 Indigenous youth perspectives on extractivism and living in a good way in the Yukon
}

\author{
Susanna Gartler with Taiya Melancon \\ and Eileen Peter
}

\section{Setting the stage}

The Yukon (see Figure 6.1) is a part of Canada's Arctic boreal forest, often portrayed as "a biological treasure, Indigenous homeland, and extractivist frontier" (Willow 2016, p. 1). This 'frontier' exists because of the Tintina gold belt, stretching from Alaska to the Yukon: a geological region rich in not only gold and silver, but also copper, lead, zinc, tungsten, and uranium (Goldfarb et al., 2000). Mineral production quickly became industrialized after the gold and silver rushes of the late nineteenth and early twentieth century (Coates \& Morrison 2005). During this history of gold and galena extraction, settlers and the Indigenous population became "irrevocably intertwined" (Winton \& Hogan 2015, p.93). The present case study asks how problems Indigenous youth in the Yukon are confronted with are intricately tied to extractivism (Klein 2011; Acosta 2013; Petras and Veltmeyer 2014) - a defining characteristic of the Canadian settler state (Bélanger 2018). Extractivism, as we employ it here, is the continuation of environmentally and socially disruptive coloniality (Willow 2016). By focusing on a resilience approach (Roe et al. 2012), this chapter sketches ideas and solutions proposed by the study participants for 'living in a good way.' Living in a good way in a Yukon First Nation context means following ethical and cultural protocols and contributing to the wellbeing of oneself and one's community (Demientieff 2017).

Indigenous peoples of the Yukon have lived on their traditional territories since 'time immemorial.' After contact with fur traders and prospectors in the late nineteenth century, Yukon First Nations gradually became part of the cash economy, while continuing to live off the land (Coates and Morrison 2005). Today, through land claims and self-government agreements, Yukon First Nations retain ownership to parts of their traditional homelands. ${ }^{1}$ Referring to the large and still unremediated mine sites near Mayo, called Elsa and Keno Hills, Winton and Hogan (2015) find that

Knit together in a complex pattern of mutual involvement and unequal impacts, the story of the Na-Cho Nyäk Dun and the Keno Hill mine is illustrative of how Aboriginal people across Northern Canada have been

DOI: $10.4324 / 9781003110019-9$ 


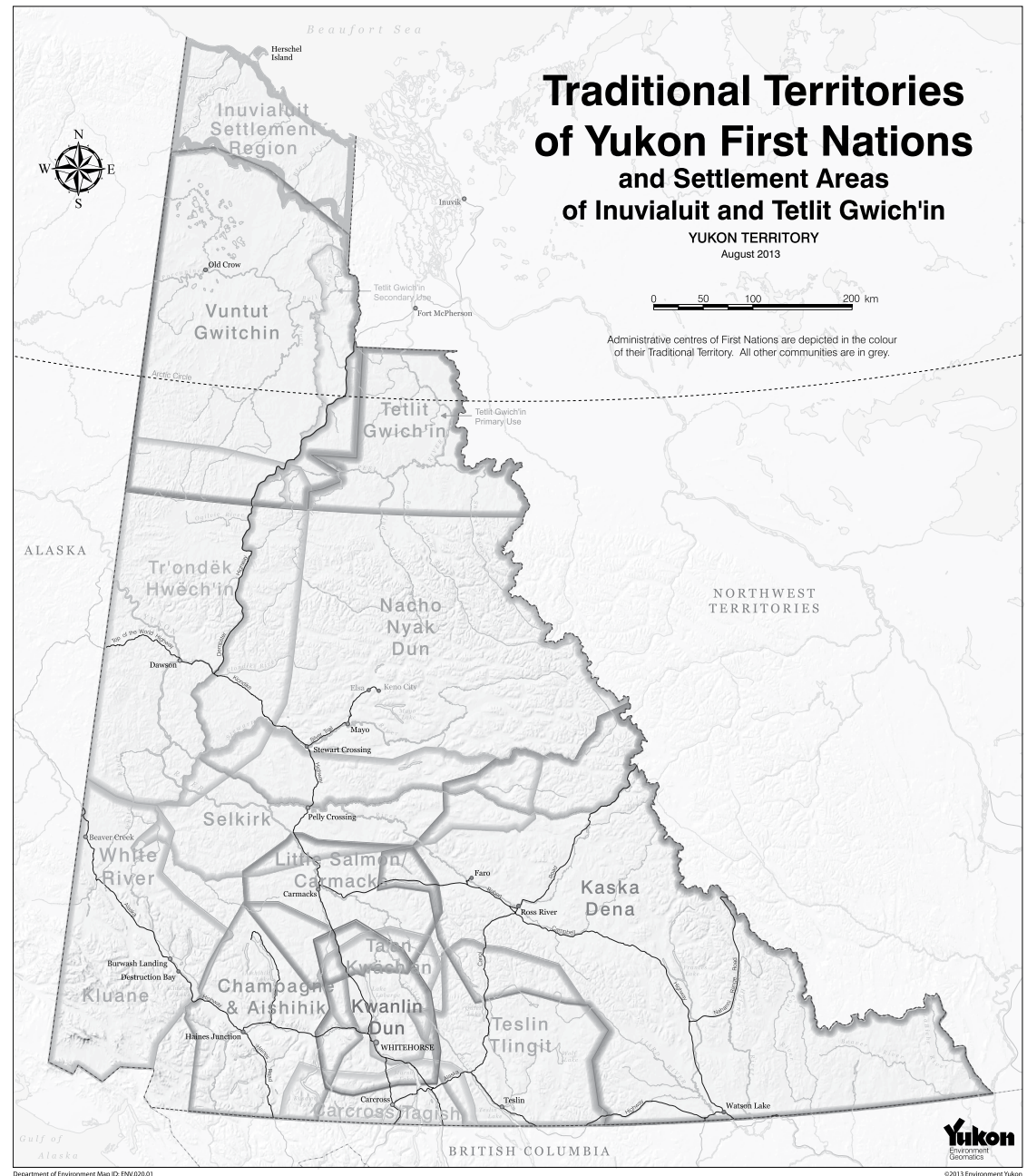

Figure 6.1 Traditional Territories of Yukon First Nations, and Settlement Areas of Inuvialuit \& Tetlit Gwich'in.

(Source: Government of Yukon)

both affected by and involved in one of the most destructive forms of industrial development in their traditional lands.

(Winton and Hogan, 2015, p. 93)

The repercussions of this accumulation by dispossession (Harvey 2003) can still be felt today, including the slow violence (Nixon 2011; Sandlos and Keeling 2016) of environmental contamination. While mining operations today benefit the local population primarily by providing job opportunities, this chapter shows that First Nation youth, and young women in particular, 
are confronted with the consequences of an extractivist, colonial, and masculinist mindset at the work place and in their everyday lives.

Not many studies focus specifically on the interplay between the extractive industry and Indigenous youth wellbeing in the Arctic and Subarctic. However, a range of related topics are being discussed, which, amongst others, form the basis of Indigenous wellbeing, such as environmental repossession (Big-Canoe and Richmond 2014), sharing practices (Rasmus et al. 2014), positive relationships (Kral 2012; Kral et al. 2014), community-led cultural revitalization (Barker et al. 2017), Indigenous youth resilience (Ulturgasheva et al. 2014; Ulturgasheva et al. 2015), safer-sex efficacy (Logie et al. 2019), suicide prevention (Rasmus et al. 2014; Talaga 2020), and Indigenous - state relations (Dhillon 2017). This chapter contributes to this body of literature by highlighting a selection of Indigenous youth concerns that are connected to the mining industry and a colonial past.

This chapter is divided into two sub-sections: 'There needs to be balance' describes problems connected to the labour market, such as worker satisfaction, gendered biases in the workplace and (coping with) drug abuse and addictions, as well as protecting the environment and revitalization of onthe-land skills in the face of climate change. 'Northern Tutchone Strong' discusses fostering intergenerational understanding and lateral kindness through youth initiatives as well as the use of technology and parenting skills. This section emphasizes the role of education and schooling as well as Indigenous languages and culture and strengthening connections through ceremony, art, and play. The chapter shows how these, at first glance seemingly unrelated, phenomena are structurally tied to each other through extractivism.

\section{Living in a good way and extractivism}

Generally speaking, living in a good way means following ethical and cultural protocols and codes of conduct in Yukon First Nations contexts (Demientieff 2017). Living in a good way from the perspective of young people living in the Yukon also means doing good things, in the right way. A 27-year-old entrepreneur and youth advocate - who self-identifies as Ojibwe, Northern Tutchone and Kaska Dene - explains: "You always hear that in Indigenous culture everywhere, that we need to live in a good way. You do good things; good things will come." A concrete example would also be the Ojibwe/ Anishinaabe concept of Pimaa-tisiwin, which "does not simply imply an accumulation of 'good' things for the self, but also an ethic of goodness" (Kulchyski 2005, p. 113). Living in a good way and Indigenous wellbeing is intricately tied to connection to ancestral land (Bhattacharyya et al. 2013; Petrasek MacDonald et al. 2015).

Extractivism-also coined "extractive imperialism" by Petras and Veltmeyer (2014) - disrupts Indigenous connection to land, and is based on the export of primary commodities (Acosta 2013), associated with high poverty levels, uneven wealth distribution and imperialist systems (Willow 2016). 
Defined "as an environmentally and socially destructive extension of an enduring colonial societal structure" (Willow 2016, p. 1), Klein (2011) notes how extractivism is bound up with the idea of a limitless nature. Sehlin MacNeil (2017) develops the concept of extractive violence in relation to Indigenous peoples' "as violence against people andlor animals and nature caused by extractivism, which predominantly impacts peoples closely connected to land" (ibid., 2). Extractivism "reproduces the resource colonialism of old" (Willow 2016:13), benefiting those most who are already empowered-while locals bear the most of the environmental and social risks (Burke 2012).

\section{Methods and methodology}

Following Indigenous methodologies of reflexivity and accountability (Chilisa 2012; Russell-Mundine 2012; Smith 2012; Rasmus 2014), I will briefly present my own background: Born in Austria to an Austrian father and a Czech mother, I studied Social and Cultural Anthropology at the University of Vienna, where I am currently enrolled in a doctoral programme. My previous engagement with subsistence, land use and Indigenous self-determination (Gartler 2018) engendered my interest in the Arctic and Subarctic. Researchers working in the Yukon are required to obtain a research license and ethics approval prior to commencing their work and First Nations' permission to conduct fieldwork. Collaboration with First Nations is strongly encouraged, enabling co-design of research aims and methodologies. Between 2014 and 2019, I was co-investigator of the community-based participatory project " "LACE_Labour Mobility and Community Participation in the Extractive Industry Case Study in the Yukon Territory (2014-2019)" (Saxinger 2018) and worked with the Heritage Department of the First Nation of Nacho Nyäk Dun (FN NND) on a variety of themes, including oral history, language revitalization, preservation of heritage sites, and the planning of a cultural centre. ${ }^{3}$

This chapter is based on participant observation at a variety of Indigenous youth and cultural events and informal conversations conducted throughout 2014 to 2019. It is also based on semi-structured anonymous interviews conducted within the framework of LACE with six Indigenous mine workers. Moreover, two First Nation of Nacho Nyäk Dun youth councillors ${ }^{4}$, one young member of the Heritage Department and a FN NND community education liaison coordinator (now former positions), as well as an Indigenous youth advocate participated. Data collection also included co-creation of knowledge through research-topic and collaborative yarning (Bessarab and Ng'Andu 2010) with two young FN NND citizens (one male, one female), and one semi-structured interview with a non-Indigenous female, as part of the project Arctic Youth and Sustainable Futures. ${ }^{5}$ All participants were asked to review an earlier version of this chapter and whether they wanted to be co-authors. Two of them, Taiya Melancon and Eileen Peter (both FN NND citizens), accepted the invitation.

At the time of the interviews all participants were under the age of 30 . The research sampling of participants between the ages of 18 and 30 corresponds 
to local definitions of youth (see e.g., Council of Yukon First Nations 2020). However, First Nation definitions are more complex, as this participant explains:

As I have always been taught, you are a young person until you find out what your gifts are. When we find those gifts, our job is to give things away - and then we find our journey. And when we find our journey, we become an adult. These are the steps in life that we take.

These thoughts resonate with Indigenous scholar Marcus (2016, p. 359) who explains that being aware of your gifts and talents entails a sense of being in place, socially, and physically: "By being mindful of the gifts of our lives within our own talents and abilities, we become more attuned to our place within our community and the environment." Most interviews took place on the traditional territory of the First Nation of Nacho Nyäk Dun, and on the traditional territory of the Kwanlin Dün First Nation and the Ta'an Kwäch'än Council. We wholeheartedly subscribe to the call to challenge the "deficit framing of the Aboriginal situation" (Parlee and Marlowe 2002): This chapter thus addresses not only problems Indigenous youth and young adults in the Yukon face but also discusses how to resolve these problems - thus employing a resilience and asset approach (Roe et al. 2012).

\section{"There needs to be balance": protecting nature and climate, jobs and the work environment}

The two main drivers of the Arctic economy today are subsistence harvesting and the extraction of renewable and non-renewable natural resources (Holen et al. 2015; Larsen and Huskey 2020), which are mostly sold to regions far South of the subarctic boreal forests. Resource revenues from mineral extraction are difficult to estimate, but research has shown that local financial benefits have been limited in the past (Huskey and Southcott 2016). Prices are generally higher in remote northern communities, and housing can become scarce due to the industry's demands. However, mining brings benefits too, such as employment, scholarships and royalties (especially if the mine is operating on Category A land).

General opinions around mining usually revolve around two issues in the Yukon: Jobs and the Environment. This young miner echoes the opinion of many, including First Nation of Nacho Nyäk Dun Elders (FN NND Elders et al. 2019): "Mining isn't a good or a bad thing really. Because you are destroying lots of stuff and you are polluting the water. At the same time, it has given people jobs and employment." In contrast, this youth advocate shares his relational view:

My teachings, they say that anything that disturbs the land, unless you give back, isn't good. Everything underneath the earth is connected. So, when you disconnect what is underneath, you mess up the eco system and the relationship between you and the land. 
Yukon Indigenous peoples traditionally consider themselves part of the land and part of the water (McClellan et al. 1987). He adds that "the least you can do is reclaiming the land: Make sure you return the land to how it was when you got there - considering you are going to do it either way." Balance is a concept that often comes up in connection to a reciprocal relationship with land (see e.g., Trinidad 2012) and mining, as this youth councillor says:

My personal opinion is that it needs to be balanced. It brings a lot of opportunities to youth, and a lot of economic development, it generates income for families. But the mines also need to respect our opinion, work with us, talk with us and negotiate based on mutual respect.

Attitudes towards working in the industry differ from person to person: some perceive the working conditions of rotational shift work as overpowering; others adjust to it more easily (Saxinger and Gartler 2017). Experienced miners recount that on-the-job, step-by-step learning and mentoring - as well as being able to adjust to the boom and bust cycles of mining - is essential (Saxinger and Gartler 2017). However, Indigenous women and men are often employed in low-paying, entry-level jobs; higher-ranking positions are often filled by experienced workers from outside the Yukon. Even fewer young Indigenous female - or 2SLGBTQQIA — persons are currently in leadership positions in the industry. Some Indigenous young people enjoy shift-work, are able to take advantage of the opportunity to work for high wages, and build their professional careers over time, whether through direct employment or by building their own companies. Two young members of the FN NND offer a differential view on the effects of the mining industry on the job market. When asked about work opportunities - at a time when a large gold mine had already started operating in the vicinity of her hometown - one answers promptly: "There's tons of jobs. If you want to work, you can." Her friend, however, remarks: "Yeah, but the jobs are only in the mining industry. It's where you get the most jobs with the highest pay." Reflecting on the very specific social and spatial setting of mine camps with strict rules and regulations (see Saxinger et al. 2016) he adds: "It's like going to prison." Other youth, however, do not see routines at camp and personal freedom as contradictory, suggesting that satisfaction with this type of work is dependent on individual preference - as well as family background. One participant, whose male family members have worked in mining for generations, responds by affirming that good camp food and good wages contribute significantly to worker satisfaction: "Yeah, but you get paid a lot. And the food is really good!"

Having access to locally hunted and harvested foods is an important part of living in a good way in the Yukon. However, large-scale mining operations often not only go hand in hand with accumulation by dispossession (Holden et al. 2011) but also with "the suppression of alternative (Indigenous) forms of production and consumption" (Harvey 2006, p. 153). Good wages often allow workers to buy hunting, fishing and trapping equipment and long periods at home often allow for enough time for these activities 
(Saxinger and Gartler 2017). At the same time, rotational shift work can present significant barriers to: (1) being on the land, by taking away time for hunting trips (Nelson et al. 2005); (2) participating meaningfully in community life; as well as (3) meeting childcare obligations (NIIMMIWG 2020, p. 593). A young worker explains: "When I come home from my shift I want to be with my family, go trapping and hunting, do my sewing and beading, all those things I don't have time for when I'm away."

Combining rotational shift work with being on the land, community, and family life is essential for living in a good way for Indigenous (and many non-Indigenous) workers. Through warming weather and other local impacts of climate change, however, it becomes harder to navigate safely on the land and to correctly assess indicators of risky conditions (Laidler et al. 2009 , p. 388). In addition, several study participants noted that as on-theland skills are being pushed to the margin by today's consumer society, skills such as navigating without instruments, dressing appropriately, and knowledge of the right equipment are increasingly lost. Thus, local impacts of climate change and the legacy of an extractivist system, which systematically devalued Indigenous ways of knowing, makes moving on the land and water increasingly difficult and unpredictable (see e.g., IRC 2016). Capitalogenic global warming, caused by excessive extraction, misappropriation and irresponsible use of resources (Harvey 2007; Malm and Hornborg 2014; Moore 2015; Bartolovich 2019) is also raised by a young man, who recently participated in Tracking Change, a program that brought him to the UN Climate Conference COP24 in Poland. He asserts what has become common knowledge in the past years: "Climate change is happening in the Arctic and Subarctic, and it's three times faster here than in most places" (see also Bush and Lemmen 2019).

Learning how to adapt to a changing environment by spending more time on the land is a major concern for youth living in the Canadian Arctic. The Indigenous Youth Podium Discussion at the Adäka Festival in Whitehorse in 2016 addressed how to incorporate more Indigenous ways of being into their lives while being integrated in the modern world. One participant explains: "Our elders are saying now that what we have done to the world, we cannot take back. We now have to live with what we have done, but we have to be positive as young people." In response to these issues, in late 2020, the Council of Yukon First Nations, the Assembly of First Nations and the Yukon Region and Youth Climate Lab launched a call for 12 Youth Yukon First Nation Climate Action Fellowships.

\section{Addictions, sexism, and workplace harassment}

Extractivism has not only had profoundly negative impacts on the environment, mining colonialism has also gone hand in hand with assimilationist policies, the repercussions of which pose significant barriers for Indigenous youth to become resilient and strong leaders. Substance abuse, bullying, lateral violence and intergenerational blame which are linked to the Canadian 
Residential School system (Bombay et al. 2014), can be regarded as part of an extractivist past and present too. Two young adults agree that their generation wants to break out of the cycle: "We see it all around us, but we don't want to be like that." Some youth are speaking on social media about how abuse of drugs is affecting their families and communities. One participant explains why addiction matters to her-a problem commonly associated with communities near mines (see, e.g., Gibson and Klinck 2005): "Drugs and the problems associated with that are real, maybe that is why I talk like that, why I am so angry." However, for some, selling drugs is a way to ensure an income in an environment where not many opportunities present themselves, as well as during recessions or mining busts. A young employee at a mine admits:

A few years ago, during the world economic crises, I got involved with a gang and sold a lot of drugs. They are worth way more in the North, so I moved here. But then I got a job really quickly, and slowly fell away from that. So, work has been really positive in my life, helping me with my problems.

Other young mine employees share that being in camp for two weeks helps them get away from their everyday problems and (bad) habits. Another participant, who himself went through alcohol abuse and was able to heal himself, shares that ways of helping peers are numerous, such as creating your own organization, or simply talking to people, making sure they have someone to confide in.

Trust and confidence are important elements of workplace safety. In Canada, female employment in mining makes up $14 \%$ of the workforce (Natural Resources Canada 2019). Not all experiences of young womenwhether Indigenous or non-Indigenous - are good though, and sexist behaviours and assumptions still prevail in an "often hypermasculine and hypersexualized" (NIIMMIWG 2020, p. 593) work environment, at both the blue- and white-collar levels. A 27 -year-old non-Indigenous Canadian professional working closely with industry proponents, explains:

Drillers and other trades people do a lot of 'boys talk'. It's very direct, as a woman you have to adapt to the male environment. The business man coming from the South will be subtler, carrying sexist assumptions, thinking you are there to take notes, or ignoring you. It's like a 'boys can talk to the boys' club. Men in the (mining) industry still have a hard time acknowledging that - especially young — women can be in leadership roles.

A young Indigenous housekeeper at a mine camp notes that harassment can be rather subtle too: "I have an admirer out here he just likes to stare at me. It's really annoying. If he doesn't stop soon, I'll have to say something." However, harassment is not confined to camps and happens in communities 
too. The connection between violence, colonialism, land rights, mining, female bodies, and youth was observed a very long time ago by Indigenous activists, as Clark (2016, p. 49) notes:

[...] early Indigenous activists such as Zitkala-Sa and Winnemucca (1883) were central to fighting the issues of violence on the land and on the body as they witnessed it at the turn of the century. [...] Zitkala-Sa and other Indigenous feminists remind us again and again in their writing that violence has always been gendered, aged, and linked to access to land.

The connections between resource extraction, substance abuse, and violence against Indigenous women, girls and 2 SLGBTQQIA $^{6}$ people has been pointed out in the Report of the National Inquiry Into Missing and Murdered Indigenous Women and Girls (NIIMMIWG 2020). Linking extractivism and the (failure of) recognition of Indigenous rights to violence against 2SLGBTQQIA people, Indigenous women, and girls, the report calls upon the extractive industry and its workers to address "situations in which violence is [perpetrated,] ignored and normalized as part of the work environment" (NIIMMIWG 2020, p. 593) — among many other recommendations. Companies in the Yukon are required to have strict policies to deal with perpetrators, who are - ideally but not always - terminated and sent home immediately if an incident occurs. Other coping mechanisms include enlisting allies, support circles, using media to speak up, and informing the public or management of the company if any transgressions occur.

A youth advocate stresses the need for strong future leaders to implement necessary changes for environmental protection and a safer work and home environment for all: "We need to make the younger people stronger, so that we will have future leaders that are going to uphold the protection of our people, the land, water and the air." Big-Canoe and Richmond (2014) call for 'environmental repossession' as a response to disconnection from and dispossession of land. In response to the court case surrounding the Peel Water Shed, the FN NND has organized several "Youth of the Peel"7 canoe trips in recent years, to promote strong ties to land, culture and community (Petrasek MacDonald et al. 2015), and to promote knowledge transfer between Elders and youth. They also sent some youth to the Supreme Court in Ottawa for the final decision in the case. In the words of a youth councillor, this was

to show young people why we do what we do and why are we protecting this area from mining and exploration. You got to show them one on one, also how far we will go to protect something we believe in.

She explains,

Being Northern Tutchone in my own view means knowing the land, respecting it and treating everyone with respect. We say we are the 
protectors of the land and the water. That's what being Northern Tutchone means to me.

Positions such as the youth councillor within a First Nation government are designed to build confidence and leadership skills. On-the-land initiatives such as Youth of the Peel and cultural camps include the transmission of traditional laws - such as respecting Elders and living in a good way, according to Doo'Lí laws (Natcher and Davis 2007) and the Northern Tutchone Code of Ethics - and knowing how to hunt, trap, fish and gather, and process plants and medicine. At the same time, young Indigenous adults take matters into their own hands as this story, shared by the young heritage and culture worker, shows:

We formed a group, it's called Yukon First Nation Emerging Leaders ${ }^{8}$ and that was made by young people for young people. And we organized the first ever Yukon First Nation Youth Conference that brought together youth from the whole Yukon. It was a three-day camping trip; we made sure it was on the land and it was amazing.

A variety of youth-initiated and First Nation programs and activities foster healthy living, intergenerational understanding and lateral kindness, including 'Youth for Lateral Kindness' founded by two members of the Kwanlin Dun First Nation in 2016 (CBC News 2017). Many other initiatives foster leadership, such as First Nation Youth Gatherings, the Yukon Youth Healthcare Summit (which won the Arctic Inspiration Price in February 2020), Yukon Youth organizations such as BYTE (see yukonyouth.com), sports events like the Yukon Native Hockey Tournament, education and career support projects like Northern Compass, and the Arctic Indigenous Youth Leaders' Summit, taking place in 2019. The next section deals with some barriers to effective leadership, such as grief, lateral violence, and intergenerational blame, and how they affect young Indigenous people's lives - while suggesting ways to overcome these structurally embedded effects of extractivism.

\section{"Northern Tutchone Strong": language revitalization, education, ceremony, art and play}

Knowledge we regain, culture is my life

Smudgin' on the sage, that's my right

Are we on the same page, culture take flight

Sitting in class, no end in sight

Just want to be outside, out where them trouts dive

Me and my homie Jeremiah gonna fly

We can tell our kids we didn't let our culture die

Strive to survive, keep our language alive

(Song text by Driven to Change 2018) ${ }^{9}$ 
Community- and youth-led cultural revitalization is generally acknowledged as crucial to enhance Indigenous youth resilience and wellbeing (e.g., BigCanoe and Richmond 2014; Ulturgasheva et al. 2014; Hatala et al. 2017), and also in relation to a pandemic of another kind: youth suicide (Barker et al. 2017). Suicide disproportionately affects Indigenous boys and young men but also girls and young women in Canada (Kral 2012, 2013). An abrupt death and a lack of coping mechanisms within the family and social group can put enormous pressure on young people. A youth councillor summarizes preventive measures:

We are putting a lot of effort into wellness, but sometimes there are unfortunate events that trigger a downward spiral. We are such a small community, sometimes there is nothing to do and that's where it all starts. People need opportunities to work, to have access to housing and to take part in land-based initiatives: these are the three things to keep our people healthy. And a good, low-threshold, easy-to-access support system, with councillors who live in town.

In the case of Mayo, these challenges are taken on by the community as a whole, but they require a very sensitive and open engagement with the colonial past and present, which is unfortunately not always the case. Opinions amongst some non-indigenous Yukoners, such as that First Nation's people should 'finally get over it', still exist. However, this kind of opinion does not acknowledge the communal effort it takes to reconcile with a violent past: If the inflicted violence is rooted in collectively held opinions and acts, only combinations of individual and collective approaches to healing can afford results (see, e.g., Lavallee and Poole 2010).

Language revitalization is an integral part of Indigenous resurgence. Language, as a means of expressing cultural knowledge (Marcus 2016), is "one of the biggest things that we are trying to revitalize everywhere", in the words of a youth advocate. Northern Tutchone is being taught at the local school in Mayo, but participants in the study stress the room for improvement. First Nations languages are key to re-indigenizing life in the North and should be taught at all levels starting at the day-care, a young FN NND citizen declares. His friend adds that "it's harder for us to revitalize our language and culture, when we don't really know how. But we know that there are things like language nests and immersion programmes, which work really well in other places." The two reflect on how revitalizing language and culture is much harder in a place so heavily affected by mining, however: "This town is definitely more colonized than any other place, because this place was built around a mining community." Other communities which don't have mines "definitely have more First Nations who know what they're talking about and who know what they're doing. So, it's kind of difficult for us. Because we're so ... adapted." The short pause she adds before the word 'adapted' points to a salient issue: Adaptation and flexibility are attributes commonly associated with First Nation, Inuit and Métis peoples (see e.g., Gartler et al. 2019). 
However, if Indigenous peoples across Canada would have been able to adapt on their own terms to settler society - instead of being forcibly assimilatedthe 'Settler problem' (Taiaiake Alfred in Regan 2010, p. x) would have been much less aggravated than it is today.

Mining provides the resources to build 'brand-new trucks' (a very popular commodity in the Yukon, also among Youth), ATV's, skidoos, other outdoor equipment as well as the electronic gadgets the younger generations are so fond of and accustomed to. While younger children play outside, it is often hard to pry teenagers and young adults away from their electronic devices. The excessive use of technology is frequently called out as a problem by youth and young adults themselves, although there are not just negative aspects to technology: snowmobiles and GPS, for example, enable young hunters to pursue subsistence activities without the years of experience needed to deploy a dog team or navigate using traditional methods (Laidler et al. 2009, p. 389). Moreover, youth agree that taking advantage of information technology to bring back cultural understandings and learning First Nation languages is very useful.

Whether through individual or collective action, face-to-face interaction or using the technological possibilities now available, Indigenous youth identify revitalizing culture and language as an integral part of the path towards healing and achieving community wellbeing. Part of Indigenous resurgence is an active stance against the negative effects of the Canadian Residential School system and the acknowledgment that it did not all happen in the distant past. A youth councillor explains:

Fighting the effects of residential schools is a slow process. Lots of people think it was a long time ago, but it's not, it's our parents' generation too. And we are just still fighting all the things that came from it.

Another major problem associated with the Canadian Residential School system, which is identified by both a FN NND youth councillor and a longterm youth advocate, is parenting skills. In response to this problem, a Parenting Support Group was founded by a youth advocate and two other individuals in Mayo to give support to young parents and single mothers.

A youth councillor explains:

First Nation people are slowly building themselves back and getting back to how we were before colonialism. This includes having things that grounded us, like to get our language and culture back, that will create a better future for our people. And we try to build up healthy young aboriginal people, what we call 'Northern Tutchone Strong'-having strong individuals, that can fight for our people in the future. And not only our people, but First Nations in general.

When asked how the younger generation envision their future, the member of the FN NND Heritage and Culture department explains: 
Less talking - more action. In the office here you get caught up with paper work so much and talking about things, instead of just doing it. I think youth are more action based. They brought so much energy and ideas to the Yukon First Nation Youth Conference I was part of this year.

Her statement mirrors the grievance that Yukon First Nations had when building government structures in accordance with the colonial system in order to be legitimate for the Canadian state and enter treaty negotiations, thereby ironically undermining long-standing principles of Indigenous governance (Nadasdy 2017). Moreover, as gold and other mineral prices skyrocket during economic crises (such as after 2008 and again in 2020), First Nation self-governments can become inundated with requests from mining proponents to claim stakes and conduct exploration on their traditional territories. A youth advocates expresses this as follows: "We are using the system now that was designed to destroy us. That is so misguided." Governance structures thus need to be revitalized alongside language and all other aspects of Yukon First Nation cultures, such as education.

Indigenous education and schooling have a long and difficult history in Canada, and exemplify the destructive effects of a colonial, extractivist history and its effects on Indigenous identity. Recent detection of mass burials near former residential schools sparked renewed debate around Canada's attempted genocide of First Nations, Métis and Inuit peoples and brought the issue to the attention of international audiences (Assembly of First Nations 2021). Schooling today has been identified both as a resource for youth wellbeing as well as a source of challenges in the Arctic (Ulturgasheva et al. 2014, p. 739). "I think the school system is challenging" observes one youth, and adds that "teachers should be trained on the history of aboriginal people and what comes along with that". Her friend concurs and remarks upon missing qualifications of teachers as well as the lack of Indigenous teachers. The young woman explains that she wants her grades to reflect her actual skills, and that she feels she would be getting a better grade "learning about my history and First Nations. That's where it's easy to connect to for me." Learning about place and their traditional territories is part of the processes of reinhabitation and indigenization within the Critical Indigenous Pedagogy of Place approach (Trinidad 2012). An important aspect of this approach, and the traditional style of education among Yukon First Nations, is to learn by listening, watching, and doing on the land. Although First Nation content is actively integrated into the school curriculum through a FN NND Community Education Liaison Coordinator in Mayo, he notes that how much happens depends on teachers and how open they are to the First Nation curriculum:

I like to bring in Elders and organize a lot of events here at the school. Recently, we had drum making, we have trapping, hunting, and fishing programs, and culture camps. But I believe that it's never enough, while at the same time a lot of these classes are trying really hard. 
Marcus (2016, p. 356) explains that "[f]or traditional Indigenous communities, ceremony is a way of life." Indigenous ceremonial and spiritual practices such as smudging or offering tobacco, and arts like painting, weaving, storytelling, carving, beading and sewing, singing, dancing, and playing instruments, alone or in groups such as the women's drum group in Mayo called 'Rammi Elin', the Dakwäkäda Dancers or the Selkirk Spirit Dancersincluding ceremonial components embedded in these practices - are increasingly popular and inspire youth from the early ages onward. After decades of repression, the tide might be turning again; the young member of the FN NND Heritage and Culture Department explains:

The new generation, the young kids, they are so hungry and interested in those types of things. At culture camps, all the kids are trying to bead and cut the fish and tan the hides. They are right in there.

Young adults also actively reclaim the way their ancestors lived: "I still go hunting. Last time, to honor my grandma, I did it the traditional way, by walking." The First Nation of Nacho Nyäk Dun encourages youth and young adults to participate in activities and many actively seek to learn traditional practices, in their homes, during culture weeks and camps, and as part of the First Nation school curriculum. Other traditions are being actively promoted too, such as the 'First Hunt', which initiates a young man (or woman nowadays) into adulthood, according to a FN NND Community Education Liaison Coordinator. Rasmus et al. (2014) emphasize the importance of support groups and sharing practices over market relations for youth wellbeing in Arctic communities (see also Ulturgasheva et al. 2015, p. 752). If the First Hunt is successful, the caribou or moose meat is then shared with the wider community and especially Elders.

Being on the land and cultural practices foster what Marcus (2016, p. 359) calls the guiding principles of relationship, respect, responsibility, and reciprocity, which are "understood through Indigenous ceremony". Many young artists combine their artistic practice with a critique of the status quo and a focus on indigenizing, self-determination, exploring Indigenous forms of selfgovernance, as well as re-connecting to spiritual and ceremonial practices and beliefs (see also the quote at the beginning of this section of a rap song by Driven to Change 2018; and interviews with young artists in Gignac 2019; Liu 2019). On a scale from cultural embeddedness to disconnection 'the Yukon is coming back', a youth advocate rejoices. When young Indigenous adults speak of cultural embeddedness and connection the above-mentioned principles of relationship, respect, responsibility, and reciprocity come to mind. During traditional hand games, for example, youth and young adults come together to have fun and to celebrate such collectively held values (see Figure 6.2). One of the organizers explains: "It's more than just about winning the tournament, it's about the community and the environment. That's what our people represent as a community: we come and work together and help each other." A youth advocate confirms the overall spirit that can be felt during everyday life, and at 


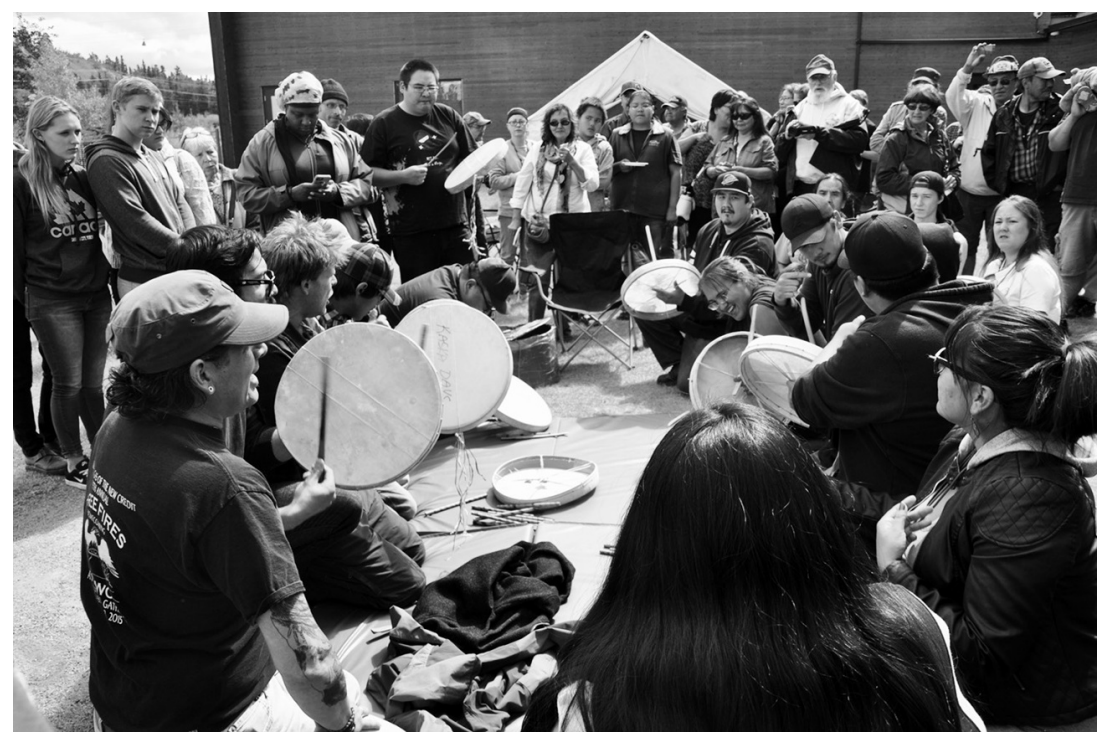

Figure 6.2 Hand games held at the Kwanlin Dun Cultural Center in Whitehorse in 2016 during the Adäka Festival.

(Photo: Susanna Gartler)

cultural events in the Yukon: "We are re-claiming who we were. We are trying to figure out who we are, where we are coming from - and we're revitalizing a lot of things. We are in a really beautiful state right now."

\section{Discussion and conclusion}

An extensive study on diamond mine development with Ticho youth in Behchokò, Northwest Territories, highlights various - not only negativeimpacts of the extractive industry, such as increased population transience, tensions between work and education, mines as community resource, including a positive effect on future outlook, inequities, and particular views of schooling (Davison and Hawe 2012, p. 218). The authors explain that "Contradictory findings from previous studies suggest that the impact of mining is neither easy to predict nor simple to reveal" (Davison and Hawe 2012, p. 223). From existing literature, they note several negative impacts of mining on youth in Canada such as changes in social ties and health, more sexually transmitted diseases, impacts on language and culture, and interference with traditional food sources. Increased income and economic prosperity are often cited as positive effects, but can lead to an increase in alcohol and drug consumption as well as gambling. Moreover, while educational attainment may decrease during a boom, addictions can increase and housing often becomes a problem - all of which are concerns in part confirmed by the present study.

The present case study shows that in the Yukon, mining can provide an opportunity to grow careers for young adults, to make good money and to get 
away from problems associated with living in small towns - such as feelings of intense social proximity, closeness to problems of other community members or isolation, and a lack of access to land and sense of belonging. Moreover, high wages allow workers to buy equipment and can thus facilitate subsistence living (Saxinger and Gartler 2017). However, racism, sexism, violence and ageism as well as intersectional challenges prevail, in an environment which often perpetuates toxic masculinities (see also NIIMMIWG 2020). Young women in higher positions might not be perceived as being in leadership roles, and young Indigenous women and men will often still be employed in entry-level, lowpaying jobs. From the perspective of reciprocity, mining will always remain problematic, because it 'does not give back' to the land. Moreover, recent examples of infrastructure failure show that no amount of good planning can prevent environmental disasters from happening (Sandlos and Keeling 2016; Herz 2020), and "slow violence" (Nixon 2011) will remain a problem.

Repression of culture and language, intergenerational blame, and lateral violence caused by residential schools and dispossession of land are felt acutely by young adults who want to break the cycle of abuse. Reviving Indigenous languages is seen as one of the pivotal factors to re-indigenize life in the North, but doing so can be difficult in places heavily impacted by extractive colonialism. Language itself can be seen as ritual: Just as with ceremony, it repeats its elements and varies them only according to rules defined by its grammar. Han (2019) proposes that rituals and ceremony are diametrically opposed to the industrial production logic. Following this argument, colonial extractivism could be seen as why it is First Nations languages and ceremonies which are most endangered in communities impacted heavily by the extractive industry, such as Mayo. Responsibility, reciprocity, and humility are important Indigenous values, and strengthened by ceremony, art, and play. Indigenous youth are motivated by festivals, community activities, dance groups, hand games, and outdoor/cultural camps, which enable connectivity and relationship-building - essential aspects of environmental repossession (Big-Canoe and Richmond 2014) and reinhabitation (Trinidad 2012) - building up strong future leaders and resilient peoples.

In the Yukon, the extracted minerals lie beneath a vast landscape of hills, mountains and forests, interlaced by many rivers and lakes: home to many bears, moose, caribou, a variety of birds and insects, fish and other mammals. Respecting and recognizing these other-than-human persons as ancestors, friends and teachers is one of the central aspects of a cosmology that values other-than-human beings including bodies of water and mountains not just as resources but as sentient relations (Ingold 2000; Cruikshank 2005, 2012). Maintaining a positive connection to 'all their [Indigenous] relations' (LaDuke 1999; Talaga 2020) is repeatedly emphasized as crucial by the young adults who participated in this study. Diverse opinions on many issues were expressed, but most participants stress that mining needs to be done respectfully — in a good way - by proper involvement of the local and First Nation population, values and protocols, including care for the environment and remediation upon mine closure. The systemic issues caused by mining 
colonialism or extractive imperialism/violence (Petras and Veltmeyer 2014; Sehlin MacNeil 2017) also need to be addressed - from individual behaviour modification to a change in mining companies' (speech) culture, to institutional change within authorities such as the police and social services. Systemic inequalities, rooted deeply within governance, health care and educational institutions, call for more than just reform; they also call for decolonizing state structures and indigenizing community life - and for respecting rights and working towards justice on a multitude of scales. The young adults who participated in this study have shown much passion for change, an acute capacity to identify problems, and offered fresh views and solutions. The findings of this study confirm that the impacts of mining are highly differential, cumulative (both additive and synergistic), contradictory, and sometimes hidden. They suggest that the long-term as well as the shortterm impacts are neither solely positive nor negative, and that a wide range of phenomena are structurally related to each other when seen through the lens of extractivism. Finally, it is especially Indigenous youth who continue to carry many of the burdens associated with a colonial, extractivist past and present - the same people who continue to 'strive to survive and keep their culture and language alive.'

\section{Acknowledgements}

A heartfelt Mussi Cho to everyone who shared their stories with me, to my reviewers, as well as to the First Nation of Nacho Nyäk Dun and all other Yukon First Nations who welcomed me and my colleagues and supported this research on their traditional territories. This research was conducted as part of the ReSDA/SSHRC-funded project "LACE-Labour Mobility and Community Participation in the Extractive Industry. Case Study in the Yukon Territory" (2014-2019, PI Gertrude Saxinger and co-PI Chris Southcott), and the "Arctic Youth and Sustainable Futures" project (PI Joan Nymand Larsen; funded by Nordic Council of Ministers' Arctic Cooperation Programme and the Stefansson Arctic Institute).

\section{Notes}

1 The FN NND traditional territory is $162,456 \mathrm{~km}^{2}$ large and expands into the Northwest Territories. Approximately 3\% are designated 'Settlement Land' (Category A and B). The FNNND has ownership of surface and subsurface rights on Category A lands. The town of Mayo where about half of FN NND citizens live today, was established in 1903 following the finding of rich silver or more precisely galena ore veins in the region (FN NND Elders et al. 2019). Ninety years after the establishment of Mayo, in 1993, the FN NND signed their selfgovernment agreement (Indian and Northern Affairs Canada 1993). Today, mining proponents are required to abide by the processes put in place by Yukon First Nations (see for example FN NND 2008a, 2008b, 2008c) and the Yukon state. Among the requirements are Impact Benefit Agreements, which often include provisions for local employment and supporting youth education-as well as 
assessment by the Yukon Environmental and Socio-economic Assessment Board (YESAB 2020).

2 A community-based participatory research approach, including a focus living in a good way counters deficit framing - such as a focus on Indigenous Peoples being 'at risk' or particularly vulnerable, and victimry (Roe et al. 2012; Tsinnajinnie et al. 2019) — and fosters a critical "eye opening" experience for both the researcher and participants (Cahill et al. 2008). Lindroth and Sinevaara-Niskanen (2018) emphasize if Indigenous Peoples are particularly vulnerable, this vulnerability stems from historic and contemporary forms of oppression and structural challenges.

3 During 18 months of Yo-Yo fieldwork (Wulff 2002), I co-developed science communication products such as the 'Mobile Workers Guide-Fly-In/Fly-Out \& Rotational Shift Work in Mining, Yukon Experiences' (Saxinger and Gartler 2017), the film "Mining on First Nation Land-The First Nation of Na-Cho Nyäk Dun in Mayo/Yukon Territory" (Saxinger and Gartler 2017), and 'Dän Hùnày-Our People's Story. First Nation of Nacho Nyäk Dun Elders' Memories and Opinions on Mining (FN NND Elders with Gartler et al. 2019).

4 A Youth Councillor's job is to voice Youth's concerns to Chief and Council, to bring opportunities to Youth within the First Nation, to build leadership skills and create so-called Northern Tutchone champions. (Interview with a Youth Councillor, 6 March 2017)

5 These participants were chosen due to: (1) their willingness to participate in the study; (2) their active leadership positions in respect to youth wellbeing; and (3) the relationship with the researcher (for the benefits of close relationships between researchers and participants see Ulturgasheva et al. 2015).

6 Two-Spirit, lesbian, gay, bisexual, transgender, queer, questioning, intersex and asexual (see NIIMMIWG 2020, p. 40).

7 For more information see the Websites http://protectpeel.ca/ and https://www. facebook.com/youthofthepeel/.

8 Since the interview the groups' name has changed to "Our Voices".

9 Part of the rap song lyrics of 'War Cry for Culture' by Driven to Change (2018), a song that expresses the thoughts of Yukon Indigenous Youth on the education system and colonialism (transcript by Susanna Gartler).

\section{References}

Acosta, A. (2013) 'Extractivism and neo-extractivism: Two sides of the same curse', in M. Lang, D. Mokrani, P. G. o. A. t. Development (eds), Beyond development. Alternative visions from Latin America, Luxembourg/The Netherlands: Transnational Institute Luxembourg - Rosa Foundation, pp. 61-87.

Assembly of First Nations (2021) 'National Chief RoseAnne Archibald Seeks Urgent Action from Federal Government after Release of Tk'emlúps te Secwépemc Report on Unmarked Graves.' Available at: https://www.afn.ca/category/news-media/ latest-news/.

Barker, B., Goodman, A., DeBeck, K. (2017) 'Reclaiming Indigenous identities: Culture as strength against suicide among Indigenous youth in Canada', Canadian Journal for Public Health, 108(2), pp. 208-210. doi: 10.17269/CJPH.108.5754.

Bartolovich, C. (2019) 'The common, force, and the capitalocene', Minnesota Review, 93, pp. 111-125. doi:10.1215/00265667-7737339. 
Bélanger, P. (2018) Extraction empire: Undermining the systems, states, \& scales of Canada's global resource empire. Cambridge, Massachusetts: The MIT Press. doi: 10.1111/cag.12654.

Bessarab, D., Ng'Andu, B. (2010) 'Yarning about yarning as a legitimate method in Indigenous research', International Journal of Critical Indigenous Studies, 3(50). doi: 10.5204/ijcis.v3i1.57.

Bhattacharyya, J., M. Baptiste, D. Setah, R. William (2013) 'It's who we are. Locating cultural strength in relationship with the land', in Parkins, J.R. and Reed, M. G. (eds) Social transformation in rural Canada. Community, cultures, and collective action, Vancouver/Toronto: UBC Press, pp. 211-231 doi: 10.25336/P6DK6V.

Big-Canoe, K., Richmond, C. A. M. (2014) 'Anishinabe youth perceptions about community health: Toward environmental repossession', Health \& Place, 26, pp. 127-135. doi: 10.1016/j.healthplace.2013.12.013.

Bombay, A., Matheson, K., Anisman, H. (2014) Origins of lateral violence in Aboriginal communities. A preliminary study of student-student abuse in residential schools. Ottawa: Aboriginal Healing Foundation. Available at: http://www.ahf.ca/ downloads/lateral-violence-english.pdf (Accessed: December 23 2020).

Burke, B. J. (2012) 'Transforming power in Amazonian extractivism: Historical exploitation, contemporary "fair trade", and new possibilities for Indigenous cooperatives and conservation', Journal of Political Ecology, 19(1), pp. 114-126. doi:10.2458/v19i1.21720.

Bush, E. and Lemmen, D.S. (eds) (2019) Canada's changing climate report. Government of Canada, Ottawa, ON.

Cahill, C., Rios-Moore, I., Threatts, T. (2008) 'Different eyes/open eyes communitybased participatory action research', in M. Fine and J. Cammarota (eds), Revolutionizing education: Youth participatory action research in motion, Critical youth studies, New York/London: Routledge, Taylor \& Francis Group, pp. 89-124. doi: 10.4324/9780203932100.

CBC News (2017) Yukon First Nations woman receives award for tackling lateral violence, CBC News, 8 Dec. Available at: https://www.cbc.ca/news/canada/north/ teagyn-vallevand-award-samara-lateral-kindness-1.4440709 (Accessed: December 23 2020).

Chilisa, B. (2012) Indigenous research methodologies. Thousand Oaks, CA: Sage.

Clark, N. (2016) 'Red intersectionality and violence-informed witnessing praxis with Indigenous girls', Girlhood Studies, 9, pp. 46-64. doi: 10.3167/ghs.2016.090205.

Coates, K., Morrison, W. R. (2005) Land of the midnight sun: A history of the Yukon (2nd ed.). Montreal: McGill-Queen's University Press.

Council of Yukon First Nations (2020) 'Yukon First Nation climate action fellowship'. Available at: https://cyfn.ca/climate-action-fellowship-targets-young-yukon-firstnations/ (Accessed: December 23 2020).

Cruikshank, J. (2005) Do glaciers listen? Local knowledge, colonial encounters, and social imagination. Vancouver: University of British Columbia Press. doi: 10.5038/2162-4593.11.1.9.

Cruikshank, J. (2012) 'Are glaciers 'good to think with? Recognising Indigenous environmental knowledge', Anthropological Forum, 22(3), pp. 239-250. doi: 10.1080/00664677.2012.707972.

Davison, C. M., Hawe, P. (2012) 'All that glitters: Diamond mining and Ticho youth in Behchoko, Northwest Territories', ARCTIC, 65(2), pp. 214-228. doi: 10.14430/ $\operatorname{arctic} 4202$. 
Demientieff, L. M. (2017) Deg Xit'an Athabascan conversations on wellness: A qualitative study exploring the radical possibilities of relationships. Doctoral Thesis, University of Utah.

Dhillon, J. (2017) Prairie rising: Indigenous youth, decolonization, and the politics of intervention. Toronto: University of Toronto Press. doi: 10.1353/gpq.2019.0022.

Driven to Change (2018) War cry for culture. (Song) Council of Yukon First Nations. Available at: https://www.youtube.com/watch?v=xUkiw2DnWgk (Accessed: December 23 2020).

First Nation of Nacho Nyäk Dun (2008a) 'Co-op engagement flowchart', Mayo: First Nation of Nacho Nyäk Dun.

First Nation of Nacho Nyäk Dun (2008b) 'Cooperative engagement process for economic activities proposed in the Traditional Territory of the First Nation of Na Cho Nyak Dun', Mayo: First Nation of Nacho Nyäk Dun.

First Nation of Nacho Nyäk Dun (2008c) 'Guiding principles towards best practices codes for mineral interests within First Nation of Na-Cho Nyak Dun Traditional Territory', Mayo: First Nation of Nacho Nyäk Dun.

First Nation of Nacho Nyäk Dun Elders with Gartler, S., Hogan, J., Saxinger, G. (2019) 'Dän Hùnày - Our people's story'. First Nation of Nacho Nyäk Dun Elders' Memories and opinions of mining. Mayo: Yukon First Nation of Nacho Nyäk Dun/ Yukon College/ReSDA (Resources and Sustainable Development in the Arctic).

Gartler, S. (2018) 'One word, many worlds: The multivocality of "subsistence", Alaska Journal of Anthropology, 16(2), pp. 49-63. Available at: https://www.alaskaanthropology.org/wp-content/uploads/2021/02/Gartler_forweb.pdf.

Gartler, S., Kuklina, V., Schweitzer, P. (2019) 'Culture and sustainability', in J. K. Graybill \& A. N. Petrov (eds), Arctic sustainability, key methodologies and knowledge domains. A synthesis of knowledge I. Abingdon, Oxon/New York: Routledge, pp. 61-86.

Gibson, G., Klinck, J. (2005) 'Canada's resilient North: The impact of mining on Aboriginal communities', Pimatisiwin: A Journal of Aboriginal and Indigenous Community Health, 3(1), pp. 115-140.

Gignac, J. (2019) 'Blake Shaákoon Lepine is part of a legion of artists working to change Indigenous art. The local artist has an exhibit at Arts Underground', Yukon News,3September.Availableat:https://www.yukon-news.com/entertainment/blakeshakoon-lepine-is-part-of-a-legion-of-artists-working-to-change-Indigenous-art/ (Accessed: December 23 2020).

Goldfarb, R. J., Hart, J. R. C., Miller, M. L., Miller, L. D., Farmer, L. G., Groves, D. I. (2000) The Tintina Gold Belt - A global perspective, in Tucker, T.L. and Smith M.T. (eds) The Tintina Gold Belt: Concepts, exploration, and discoveries: Special vol. 2, Vancouver, BC: British Columbia/ Yukon Chamber of Mines, pp. 5-34.

Han, B.-C. (2019) Vom verschwinden der Rituale: Eine Topologie der Gegenwart. Berlin: Ullstein.

Harvey, D. (2003) The new imperialism. Oxford: Oxford University Press.

Harvey, D. (2006) 'Neo-liberalism as creative destruction', Geografiska Annaler: Series B, Human Geography, 88(2), pp. 145-158. doi: 10.1111/j.0435-3684.2006. 00211.x.

Harvey, T. (2007) 'Challenging the planet: A call from the Arctic to face the heat on climate change', in S. Cullis-Suzuki, K. Frederickson, A. Kayssi, C. Mackenzie \& A. D. Cohen (eds), Notes from Canada's young activists: A generation stands up for change, pp. xii-226. Vancouver, Toronto, Berkeley: Greystone Books. 
Hatala, A. R., T. Pearl, K. Bird-Naytowhow, A. Judge, E. Sjoblom, L. Liebenberg (2017) "I have strong hopes for the future": Time orientations and resilience among Canadian Indigenous youth', Qualitative Health Research, 27(9), pp. 1330-1344. doi: $10.1177 / 1049732317712489$.

Herz, N. (2020) 'As Arctic warming accelerates, permafrost thaw hits Red Dog mine with $\$ 20$ million bill', Anchorage: Alaska Public Media, 1 September. Available at: https://www.alaskapublic.org/2020/09/01/as-arctic-warming-acceleratespermafrost-thaw-hits-red-dog-mine-with-20-million-bill/ (Accessed: December 23 2020).

Holden, W., Nadeau, K., Jacobson, R. D. (2011) 'Exemplifying accumulation by dispossession: Mining and Indigenous peoples in the Philippines', Geografiska Annaler: Series B, Human Geography, 93(2), pp. 141-161. doi: 10.1111/j.1468-0467. 2011.00366.x.

Holen, D., Gerkey, D., Høydahl, E., Natcher, D., Reinhardt Nielsen, M., Poppel, B., Aslakse, J. (2015) 'Interdependency of subsistence and market economies in the Arctic', in S. Glomsrod, G. Duhaime, J. Aslaksen (eds), The Economy of the North, Oslo: Statistics Norway, pp. 89-126.

Huskey, L., Southcott, C. (2016) "That's where my money goes": Resource production and financial flows in the Yukon economy', The Polar Journal, 6(1), pp. 11-29. doi: 10.1080/2154896X.2016.1171002.

Indian and Northern Affairs Canada (1993) The First Nation of Na-Cho Nyäk Dun self-government agreement. Ottawa: Ministry of Indian Affairs and Northern Development.

Ingold, T. (2000) The perception of the environment: Essays on livelihood, dwelling and skill. London and New York: Routledge.

IRC - Inuvialuit Regional Corporation (2016) 'Inuvialuit on the frontline of climate change: Development of a regional climate change adaptation strategy'. Available at: https://irc.inuvialuit.com/system/files/Inuvialuit $\% 20$ on $\% 20$ the $\% 20$ Frontline $\% 20$ of $\% 20$ Climate $\% 20$ Change-Final-Feb $2018 \% 20 \% 28$ SMALL $\% 29$.pdf.

Klein, N. (2011) 'Capitalism vs. the climate'. The Nation, 9 November. Available at: https://www.thenation.com/article/archive/capitalism-vs-climate/ (Accessed: December $232020)$.

Kral, M. J. (2012) 'Postcolonial suicide among Inuit in Arctic Canada', Culture Medicine and Psychiatry, 36(2), pp. 306-325. doi: 10.1007/s11013-012-9253-3.

Kral, M. J. (2013) "The weight on our shoulders is too much, and we are falling": Suicide among Inuit male youth in Nunavut, Canada', Medical Anthropology Quarterly, 27(1), pp. 63-83. doi: 10.1111/maq.12016.

Kral, M. J., Salusky, I., Inuksuk, P., Angutimarik, L., Tulugardjuk, N. (2014) 'Tunngajuq: Stress and resilience among Inuit youth in Nunavut, Canada', Transcultural Psychiatry, 51(5), pp. 673-692. doi: 10.1177/1363461514533001.

Kulchyski, P. K. (2005) Like the sound of a drum: Aboriginal cultural politics in Denendeh and Nunavut. Winnipeg: University of Manitoba Press.

LaDuke, W. (1999) All our relations: Native struggles for land and life. Chicago: Haymarket Books.

Laidler, G., Ford, J., Gough, W., Ikummaq, T., Gagnon, A., Kowal, S., Qrunnut, K., Irngaut, C. (2009) 'Travelling and hunting in a changing Arctic: Assessing Inuit vulnerability to sea ice change in Igloolik, Nunavut', An Interdisciplinary, International Journal Devoted to the Description, Causes and Implications of Climatic Change, 94, pp. 363-397. doi: 10.1007/s10584-008-9512-z. 
Larsen, J. N., Huskey, L. (2020) 'Sustainable economies in the Arctic', in J. K. Graybill \& A. N. Petrov (eds), Arctic sustainability, key methodologies and knowledge domains: A synthesis of knowledge I. Abingdon, Oxon/New York: Routledge, pp. $23-42$.

Lavallee, L., Poole, J. (2010) 'Beyond recovery: Colonization, health and healing for Indigenous people in Canada', International Journal of Mental Health and Addiction, 8, pp. 271-281. doi: 10.1007/s11469-009-9239-8.

Lindroth M., Sinevaara-Niskanen H. (eds) (2018) 'The neoliberal embrace of resilient Indigeneity', in Global politics and its violent care for Indigeneity. Cham: Palgrave Macmillan. Springer International Publishing, pp. 79-102.

Liu, J. (2019) 'First Nations, first-hand art: A look at Yukon artists rebuilding their culture', CBC News, 27 June. Available at: https://www.cbc.ca/news/canada/north/ yukon-first-nations-art-revitalization-1.5189360 (Accessed: December 23 2020).

Logie, C., Lys, C., Mackay, K., MacNeill, N., Pauchulo, A., Yasseen, A. (2019) 'Syndemic factors associated with safer sex efficacy among northern and Indigenous adolescents in Arctic Canada', Official Journal of the International Society of Behavioral Medicine, 26, pp. 449-453. doi:10.1007/s12529-019-09797-0.

Malm, A., \& Hornborg, A. (2014) 'The geology of mankind? A critique of the Anthropocene narrative', The Anthropocene Review, 1, pp. 62-69. doi: 10.1177/ 2053019613516291.

Marcus, D. S. (2016) 'Indigenous hermeneutics through ceremony: Song, language, and dance', in D. L. Madsen (ed.), The Routledge companion to Native American literature. Abingdon, Oxon/New York: Routledge, pp. 440-452.

McClellan, C., with Birckel, L., Bringhurst, R., Fall, J. A., McCarthy, C., Sheppard, J. R. (1987) Part of the land, part of the water: A history of the Yukon Indians. Vancouver: Douglas \& McIntyre.

Moore, J. W. (2015) Capitalism in the web of life: Ecology and the accumulation of capital (1 publ. ed.). London: Verso.

Nadasdy, P. (2017) Sovereignty's entailments: First Nation state formation in the Yukon. Toronto, Buffalo, London: University of Toronto Press.

Natcher, D. C., Davis, S. (2007) 'Rethinking devolution: Challenges for Aboriginal resource management in the Yukon Territory', Society and Natural Resources, 20(3), pp. 271-279. doi: 10.1080/08941920601117405.

National Inquiry into Missing and Murdered Indigenous Women and Girls (NIIMMIWG) (2020) Reclaiming power and place: The final report of the national inquiry into missing and murdered Indigenous women and girls (Vol. 1A). Available at: https://www.mmiwg-ffada.ca/ (Accessed: December 23 2020).

Natural Resources Canada (2019) Minerals sector employment. Information bulletin. Available at: https://www.nrcan.gc.ca/science-data/science-research/earth-sciences/ earth-sciences-resources/earth-sciences-federal-programs/minerals-sectoremployment/16739\#fn10-rf (Accessed: December 23 2020).

Nelson, M., Natcher, D. C., Hickey, C. G. (2005) 'Social and economic barriers to subsistence harvesting in a Northern Alberta Aboriginal community', Anthropologica, 47(2), pp. 289-301. Available at: https://www.jstor.org/stable/25606241.

Nixon, R. (2011) Slow violence and the environmentalism of the poor. Cambridge: Harvard University Press.

Parlee, B., Marlowe, M. (2002) Community-based monitoring: Final report for the west Kitikmeot Slave Study Society. Yellowknife: Lutsel K'e Dene First Nation, West Kitikmeot Slave Study Society. 
Petras, J. F., Veltmeyer, H. (eds) (2014) Extractive imperialism in the Americas: Capitalism's new frontier. Leiden, Boston: Brill. doi: 10.1163/9789004268869.

Petrasek MacDonald, J., Cunsolo Willox, A., Ford, J. D., Shiwak, I.,Wood, M. (2015) 'Protective factors for mental health and wellbeing in a changing climate: Perspectives from Inuit Youth in Nunatsiavut, Labrador', Social Science \& Medicine, 141, pp. 133-141. doi: 10.1016/j.socscimed.2015.07.017.

Rasmus, S. M. (2014) 'Indigenizing CBPR: Evaluation of a community-based and participatory research process implementation of the Elluam Tungiinun (towards wellness) program in Alaska', American Journal of Community Psychology, 54(12), pp. 170-179. doi:10.1007/s10464-014-9653-3.

Rasmus, S. M., Allen, J., Ford, T. (2014) "“Where I have to learn the ways how to live:" Youth resilience in a Yup'ik village in Alaska', Transcultural Psychiatry, 51, pp. 713-734. doi:10.1177/1363461514532512.

Regan, P. (2010) Unsettling the settler within: Indian residential schools, truth telling, and reconciliation in Canada. Vancouver: UBC Press.

Roe, Y. L., Zeitz, C. J., Fredericks, B. (2012) 'Study protocol: Establishing good relationships between patients and health care providers while providing cardiac care. Exploring how patient-cinician engagement contributes to health disparities between Indigenous and non-indigenous Australians in South Australia', BMC Health Services Research, 12, pp. 397-397. doi:10.1186/1472-6963-12-397.

Russell-Mundine, G. (2012) 'Reflexivity in Indigenous research: Reframing and decolonising research?' Journal of Hospitality and Tourism Management, 19, pp. 85-90. doi: $10.1017 /$ jht.2012.8.

Sandlos, J., Keeling, A. (2016) 'Toxic legacies, slow violence, and environmental injustice at Giant Mine, Northwest Territories', Northern Review, 42, pp. 7-21. doi: $10.22584 / \mathrm{nr} 42.2016 .002$.

Saxinger, G. (2018) 'Community based participatory research as a long-term process: Reflections on becoming partners in understanding social dimensions of Mining in the Yukon (Essay)', Northern Review, 47, pp. 187-206. doi: 10.22584/nr47.2018.009.

Saxinger, G., Gartler, S. (2017) The mobile workers guide. Fly-in/Fly-out \& rotational shift work in mining. Yukon Experiences. Whitehorse: Yukon First Nation of Nacho Nyäk Dun/Yukon College/ReSDA (Resources and Sustainable Development in the Arctic).

Saxinger, G., Gebauer R., Oschmann J., and Gartler, S. (2017) Film 'Mining on First Nation Land: The First Nation of Nacho Nyäk Dun', 13 min., produced by the First Nation of Nacho Nyäk Dun. Available at: https://youtu.be/u4UXywmkoqM.

Saxinger, G., Öfner, E., Shakirova, E., Ivanova, M., Yakovlev, M., Gareyev, E. (2016) 'Ready to go! The next generation of mobile highly skilled workforce in the Russian petroleum industry', The Extractive Industries and Society, 3, pp. 627-639. doi: 10.1016/j.exis.2016.06.005.

Sehlin MacNeil, K. (2017) Extractive violence on Indigenous country: Sami and Aboriginal views on conflicts and power relations with extractive industries. Umeå universitet, Centrum för samisk forskning (CeSam).

Smith, L. T. (2012) Decolonizing methodologies: Research and Indigenous peoples (2nd ed.). London and New York: Zed Books and University of Otago Press.

Talaga, T. (2020) All our relations. Indigenous trauma in the shadow of colonialism. Toronto: Scribe.

Trinidad, A. M. O. (2012) 'Critical Indigenous pedagogy of place: A framework to Indigenize a youth food justice movement', Journal of Indigenous Social Development, 1(1), pp. 1-17. doi: 10.1080/15313204.2014.903136. 
Tsinnajinnie, L. R. R., Minthorn, R. S. Z., Lee, T. S. (2019) 'K'é and Tdayp-tday-gaw: Embodying Indigenous relationality in research methods', in Sweeney Windchief and Timothy San Pedro (eds), Applying Indigenous research methods: Storying with peoples and communities, Indigenous and decolonizing studies in education, New York: Routledge, pp. 37-55. doi: 10.4324/9781315169811-3.

Ulturgasheva, O., Rasmus, S., Morrow, P. (2015) 'Collapsing the distance: Indigenousyouth engagement in a circumpolar study of youth resilience', Arctic Anthropology, 52(1), pp. 60-70. doi: 10.3368/aa.52.1.60.

Ulturgasheva, O., Rasmus, S., Wexler, L., Nystad, K., Kral, M. (2014) 'Arctic Indigenous youth resilience and vulnerability: Comparative analysis of adolescent experiences across five circumpolar communities', Transcultural Psychiatry, 51(5), pp. 735-756. doi: 10.1177/1363461514547120.

Willow, A. J. (2016) 'Indigenous ExtrACTIVISM in boreal Canada: Colonial legacies, contemporary struggles and sovereign futures', Humanities, 5(55), pp. 1-15. doi: 10.3390/h5030055.

Winnemucca, S. (1883/1969) Life among the Piutes: Their wrongs and claims. Bishop, CA: Sierra Media Inc.

Winton, A., Hogan, J. (2015) “'It's just natural": First Nation family history and the Keno Hill silver mine in the Yukon Territory', in A. Keeling, J. Sandlos (eds), Mining and communities in Northern Canada: History, politics, and memory, Calgary: University of Calgary Press, pp. 87-116.

Wulff, H. (2002) 'Yo-yo fieldwork: Mobility and time in a multi-local study of dance in Ireland', Anthropological Journal on European Cultures, 11, pp. 117-136. Available at: https://www.jstor.org/stable/43234897.

YESAB (2020) Yukon environmental and socio-economic assessment board website. The assessment process. Available at: https://www.yesab.ca/the-assessment-process/ (Accessed: December 23 2020).

\section{Interviews}

- Interview with female member of FN NND Heritage and Culture Department (58 mins). September 19, 2014.

- Interview with female FN NND Youth councillor (33 mins). October 2, 2014, Mayo.

- Interview with male mine worker (36 mins). October 3, 2014, Mayo.

- Interview with male mine worker (21 mins). October 3, 2014, Mayo.

- Interview with male mine worker (27 mins). October 15, 2014, Mayo.

- Interview with male mine worker (29 mins). October 21, 2014, Wolverine Mine Camp.

- Interview with female mine worker (37 mins). October 22, 2014, Wolverine Mine Camp.

- Interview with male mine worker (51 mins). June 28, 2015, Mayo.

- Interview with male youth (1 hour 9 mins). February 16, 2017. Whitehorse, Yukon Inn restaurant.

- Interview with female FN NND Youth councillor (55 mins). March 6, 2017, Mayo.

- Interview with female youth (1 hour 54 mins). November 8, 2018. Mayo, Yukon College campus.

- Interview with one female and one male youth, (41 mins). November 21, 2018. Mayo, Yukon College campus.

- Interview with FN NND Community Education Liaison Coordinator (41 mins). January 21, 2019, Mayo at J.V. Clark School. 